\title{
Strengthening the Quality of Ma'had Aly Graduates through Optimizing Management of Infrastructure Facilities and Lecturer Competencies
}

\author{
Badrudin \\ Universitas Islam Negeri (UIN) Sunan Gunung Djati Bandung \\ dr.badrudin@uinsgd.ac.id \\ Enjang Yusuf Ali \\ Universitas Pendidikan Indonesia (UPI) \\ enjang@upi.ac.id \\ Moh. Sulhan \\ Universitas Islam Negeri (UIN) Sunan Gunung Djati Bandung \\ muhsulhan@uinsgd.ac.id

\section{Ulfah Nurul Badriyatul Fitri} \\ Universitas Islam Negeri (UIN) Sunan Gunung Djati Bandung \\ ulfahnurulbadriyatul@gmail.com
}

\begin{abstract}
The main problem of this study is the unoptimal infrastructure management and lecturers' competence that impact on the low quality of Ma'had Aly Miftahul Huda Tasikmalaya graduates. This study is aimed to explain the quality strengthening of Ma'had Aly graduates through the optimization of infrastructure management and lecturer competence. Research on the quality of Ma'had Aly graduates has been carried out by other researchers as seen from the influence of lecturers' educational qualifications. This research is focused on investigating the influence of infrastructure management and lecturer competence in improving the quality of Ma'had Aly graduates. This study used a quantitative approach with a descriptive correlational method. The data analysis using product moment correlation analysis. The sample of this study was 50 students who graduated from 2019-2020 that were selected using proportional stratified random sampling. The results of the study concluded that strengthening the quality of Ma'had Aly's education graduates could be done through optimization of infrastructure management and lecturer competence. Infrastructure management has a significant effect on the quality of graduates by $23.4 \%$; Lecturer competence has a significant influence on the quality of graduates by $7.96 \%$; and Infrastructure management and lecturer competence simultaneously had a significant effect on the quality of Ma'had Aly's graduates by $45.7 \%$.
\end{abstract}

Keywords: Ma'had Aly, Quality of Graduates, Management, Infrastructure, Lecturer Competence

Abstrak: Masalah utama penelitian yaitu manajemen sarana prasarana dan kompetensi dosen belum optimal sebingga berdampak pada rendabnya mutu lulusan Ma'bad Aly Miftabul Huda Tasikmalaya. Penelitian ini bertujuan untuk menjelaskan penguatan mutu lulusan ma'bad aly melalui optimalisasi manajemen sarana prasarana dan kompetensi dosen. Penelitian mutu lulusan Ma'bad Aly pernah dilakukan peneliti lain dilihat dari pengaruih kualifikasi pendidikan dosen. Penelitian ini difokuskan melihat besaran pengarub manajemen sarana prasarana dan 


\begin{abstract}
kompetensi dosen terbadap peningkatan mutu lulusan Ma'bad Aly. Penelitian menggunakan pendekatan kuantitatif dengan metode deskriptif korelasional. Analisis data menggunakan analisis korelasi product moment. Sampel penelitian yaitu mabasantri lulusan 2019-2020 sebanyak 50 orang yang dipilih menggunakanproportional stratified random sampling. Hasil Penelitian menyimpulkan bahwa penguatan mutu lulusan pendidikan Ma'bad Aly dapat dilakukan melalui optimalisasi manajemen sarana prasarana dan kompetensi dosen. Manajemen sarana prasarana memiliki pengarub signifikan terbadap mutu lulusan sebesar 23,4\%; Kompetensi dosen memiliki pengaruh signifikan terhadap mutu lulusan sebesar 7,96\%; dan Manajemen sarana prasarana dan kompetensi dosen secara bersamaan memiliki pengaruh signifikan terbadap mutu lulusan Ma'bad Aly sebesar 45,7\%.
\end{abstract}

Kata Kunci: Ma'bad Aly, Mutu Lulusan, Manajemen, Sarana Prasarana, Kompetensi Dosen

\title{
INTRODUCTION
}

Entering the XXI century, the big challenge faced by all nations in this globalization era is the intense competition in various dimensions of life. The development of science and technology has brought changes in almost various aspects of life, including education. These problems can only be solved by improving science and technology. Pesantren as non-formal educational institutions are among those that have received the impact of these changes, among others, by opening Ma'had Aly as a formal education institution so that pesantren need to change their governance and leadership to become more modern in order to produce quality graduates. Management of infrastructure and lecturer competence needs to be optimized in order to have a positive contribution to strengthening the quality of graduates.

The development of education in pesantren which was originally traditional in nature has now metamorphosed into semi-modern and even modern (Cahya Edi Setyawan, 2017). Many pesantren manage education in a modern way but do not abandon the salafi culture which is the original style of the pesantren. Today many Islamic boarding schools have formal education at the elementary, junior high, high school and tertiary levels. On the island of Java, there are 8,331 Islamic boarding schools that have established formal educational institutions in addition to pesantren education.

Pondok Pesantren Miftahul Huda Tasikmalaya began to develop formal educational institutions from RA, MI, MTs, MA, to Islamic religious colleges in pesantren known as Ma'had Aly. Like other universities, Ma'had Aly graduates are required to achieve the national standard of graduate quality. To maintain the quality of graduates is not something that is easily achieved but requires deep thinking and quality learning processes or actions.

The quality of Ma'had Aly graduates must be continuously improved so as to produce superior human resources. Quality improvement efforts must be 
carried out continuously. "Indonesia needs human resources in sufficient quantity and quality as the main support in development (Yean Chris Tien, 2015)." Islamic tertiary institutions as educational institutions are expected to be able to produce human resources who have academic and professional competence to become experts in Islam (Farid Permana, 2019).

The government seeks to improve the quality of human resources to realize national development in all aspects of life. As mandated in the fourth paragraph of the preamble to the 1945 Constitution, namely the intellectual life of the nation. Article 32 paragraph 1 states that every citizen has the right to education (Ambarita, 2016). This explains that humans in Indonesia must have a noble dignity and be free from the shackles of ignorance.

In Law No. 20 of 2003 Article 3 concerning the National Education System states that education functions to develop abilities and shape the character and civilization of the nation with dignity in the context of educating the nation's life. The meaning of this law is that education does not only form intelligent people but has a mature personality so that it will grow into a generation of nations with characters that breathe the noble values of the nation and religion (Ambarita, 2016).

The government's concrete steps to advance education include providing and equalizing a higher education institution in the pesantren called Ma'had Aly in accordance with the provisions of tertiary institutions outside the pesantren. Ma'had Aly at the Miftahul Huda Islamic Boarding School has been running for five years. Ma'had Aly has an operational permit in the form of a Decree from the Ministry of Religion in 2016. Ma'had Aly is focused on studying the fields of Aqidah and Philosophy (Aqidatul Islam wal Falsafatyha). The legality of Ma'had Aly which is equivalent to higher education has been guaranteed in the Regulation of the Minister of Religion No. 55 of 2007 and Law No. 18 of 2019 concerning Islamic Boarding Schools.

As a university, Ma'had Aly is required to be able to carry out educational programs in accordance with the Regulation of the Minister of Education and Culture No. 3 of 2020 concerning National Higher Education Standards. One of the national standards is the education infrastructure standard. It is stated that each educational unit is required to have facilities which include furniture, educational equipment, educational media, books and other learning resources, consumables, and other equipment needed to support an orderly and sustainable learning process, such as building and land needs (Munjamil, 2018).

Research on improving the quality of Ma'had Aly (higher education) graduates has been carried out by a number of researchers. Research by $\mathrm{M}$. 
Rosul Asmawi (2005) shows that the strategy to improve quality higher education graduates can be done by changing the human and technological subsystems, which include: (1) students being educated; (2) lecturers as educators and lecturers; (3) facilities and infrastructure. "The research is focused on the qualifications of lecturers that require development to master and doctoral degrees, while this research is more focused on strengthening the quality of the teaching process by lecturers to improve the quality of graduates. Research Dian Indiyati, et al. (2021) concluded that Human Resources competencies have an impact on employee performance.

Previous research has shown that adequate educational facilities have a strong correlation with improving the quality of the process and learning outcomes. Appropriate learning tools can be learning media that will help facilitate the thought process through the concretization of abstract objects, as well as learning objects that will help to understand phenomena directly. Management of adequate learning and learning facilities enables students not only to learn how to know but also learn how to do, how to be, and how to live together (Alam, 2018).

Many factors affect the quality of graduates, including infrastructure, which plays an important role in the implementation of the Tri Dharma of Higher Education. Student motivation to learn is supported by good management of infrastructure. Management of higher education facilities is one of the driving forces for learning activities. Management of higher education facilities (Ma'had Aly) must be carried out through careful planning, so that it can become a good educational infrastructure, its use must be according to plan, monitor and evaluate.

Good management of higher education facilities contributes to the creation of quality learning so that it will strengthen the quality of graduates. Learning facilities also affect the quality of the process and learning outcomes. Complete learning facilities help students in learning. Conversely, the lack of learning tools or facilities will hinder student progress in learning.

Ike Malaya Sinta's research (2019) states that physical facilities for learning places greatly affect the efficiency of learning outcomes. Limited facilities and infrastructure become an obstacle for students in utilizing campus facilities so that the material taught by the lecturers does not reach the target, marked by low student understanding.

Apart from the standard of educational facilities and infrastructure, the most important thing in improving the quality of graduates is the competence of lecturers. Educators and education staff standards set the criteria for pre-service education and physical and mental eligibility as well as in-service education. The 
academic qualifications to become a lecturer are at least S2 (Article 46 paragraph 2 of the Law on Lecturer Academic Qualifications), and must master the four competencies of teachers and lecturers. The four competencies are pedagogical competence, personality competence, social competence, and professional competence (Soraya, 2018)

There is a phenomenon of irregularities in the structure of educators and educational personnel in Ma'had Aly Miftahul Huda. This is evidenced by the number of students as many as 596 people, but only 12 lecturers including mudir (chancellor) and deputy homecoming (vice chancellor). According to the student affairs section, the scarcity of lecturers was due to the recruitment of lecturers only from alumni who were declared worthy by the pesantren. They have not opened vacancies for teachers or lecturers outside the Asatidz there. This is because the yellow book material which is the subject of the course is special books that come directly from the pesantren while other books are only used as references.

One of the benchmarks for the quality of college graduates is through the achievement index (IP) (Tien, 2015). To be able to measure the level of achievement in a lecture that is occupied by someone, an achievement index is needed with an assessment form that has been determined by the educational institution. In Table 1, you can see the average GPA of graduates from students for the last 3 (three) years, as follows (Curriculum, 2019):

Tabel 1. Students GPA

\begin{tabular}{l|c|c|c}
\hline \multirow{2}{*}{ Academic Year } & \multicolumn{3}{|c}{ Reguler GPA } \\
\cline { 2 - 4 } 2016 & Min & Average & Maxs \\
\cline { 2 - 4 } 2017 & 2,53 & 2,9 & 3,86 \\
2018 & 2,54 & 2,83 & 3,41 \\
& 2,77 & 3,17 & 3,74 \\
\hline
\end{tabular}

Source: Administration of the Takhasus Aqidah and Philosophy Program, (2019)

The factors that affect the quality of student graduates at Mahad Aly Mifathul Huda cannot be separated from the lecturers. Lecturers are one of the determinants of the level of success in carrying out the process of transforming science, technology, internalizing ethics and morals. Lecturers are professional educators and scientists with the main task of transforming, developing and disseminating science, technology and art (Mochamad Hatip, Khoiriyah, Abadi Sanosra, 2018). 
In addition to lecturers, learning facilities and infrastructure are a support that cannot be ignored by their existence and role in learning success. Support for learning facilities and infrastructure is very real, especially for the growth of motivation and learning outcomes of students (Arafah, 2019). In other words, the performance of lecturers and learning infrastructure has an influence on the learning motivation of students.

Infrastructure and lecturer performance correlate with the quality of student graduates. This is pursued through improving the quality of learning. This study seeks to explain how much influence the management of infrastructure and lecturers' competence has on the quality of graduates at Mahad Aly Miftahul Huda Tasikmalaya.

\section{RESEARCH METHOD}

This research uses a quantitative approach with quantitative correlational methods. This study aims to determine the relationship of several variables without manipulating these variables (Siregar, 2015). The relationship between some of the variables sought in this research method is stated in the correlation coefficient and statistical significance. The existence of a correlation between some of these variables does not mean that there is a cause and effect relationship between the variables.

This type of research is a quantitative descriptive study. The nature of this research is descriptive explanatory Sugiyono (2006, p. 30) states that descriptive explanatory research is a study that intends to explain the position of the variables studied and their relationship between one variable and another. This study examines the influence of infrastructure management and lecturer competence on the quality of Ma'had Aly Miftahul Huda Tasikmalaya graduates.

The research location was Ma'had Aly Miftahul Huda Tasikmalaya. Sources of data in this study were obtained from two sources, namely primary and secondary data. Primary data obtained by researchers by distributing a questionnaire (questionnaire) designed in accordance with the variables and indicators and items that have been set. Meanwhile, secondary data was obtained through the collection of documents that already exist in the research institution in the form of data from the administrative and academic bureau of student affairs and the quality assurance unit. The results of the questionnaire obtained by the researcher were then processed and analyzed according to the purpose of the study.

Data analysis used descriptive statistical analysis by calculating the product moment correlation and hypothesis testing. The prerequisite analysis test used the validity test and the reliability test. The prerequisite test is carried 
out to determine the quality of infrastructure management, lecturer competence, and quality of graduates. The data analysis technique used normality test, linearity test, descriptive analysis, multiple correlation analysis, multiple regression analysis and the coefficient of determination. While the hypothesis test is used to test the research hypothesis using $\alpha=0.05$ using the $F$ test and the $\mathrm{T}$ test. This hypothesis test is used to determine the relationship between the three variables, namely infrastructure management, lecturer competence, and the quality of ma'had aly graduates.

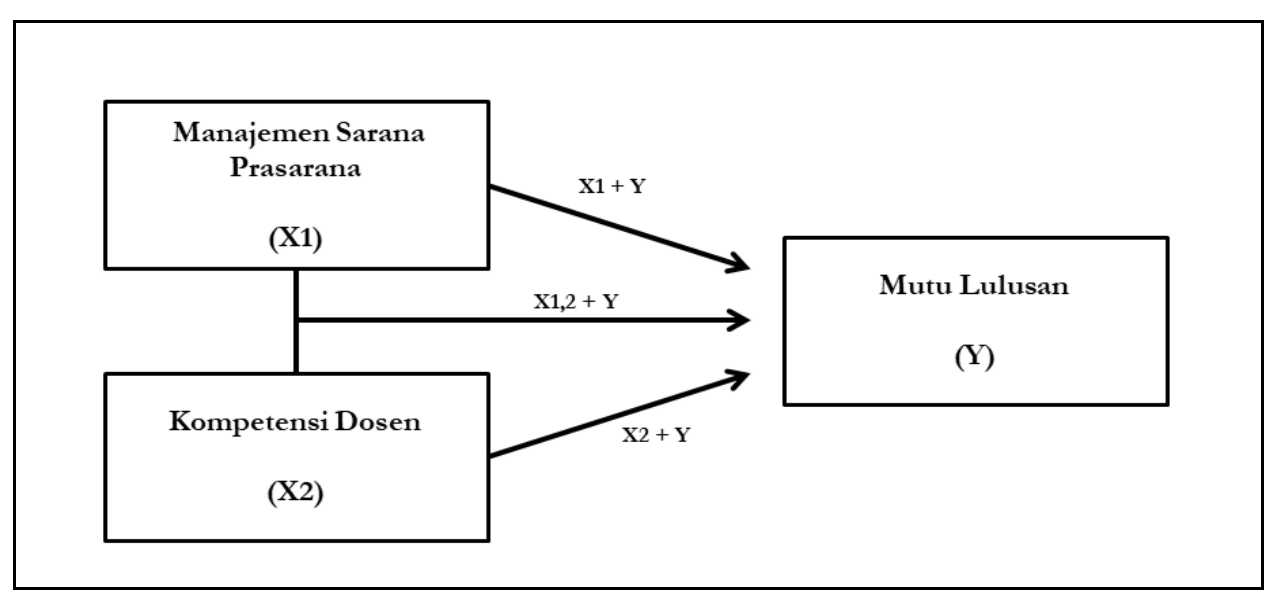

Figure 1. Hypothesis Model among research variables

\section{RESULTS AND DISCUSSION}

This study adopted the Statistical Package Analysis for Social Sciences (SPSS) and reliability tests. The sample in this study was 50 students of the 2019-2020 batch of Ma'had Aly Miftahul Huda Tasikmalaya graduates who were taken by proportional stratified random sampling.

\section{The Influence of Infrastructure Management on the Quality of Ma'had Aly Graduates}

Educational facilities are facilities that are used directly in the teaching and learning process so that learning objectives are achieved, such as buildings, classes, tables, chairs, and learning media tools. Meanwhile, educational infrastructure is anything that indirectly supports the educational process, such as gardens, yards, parks and roads. Educational facilities and infrastructure play an important role because the quality of education can be improved through the provision of facilities and infrastructure. Management of infrastructure facilities in this study is the implementation of management functions in managing the infrastructure of Ma'had Aly. 
According to Arafah (2017, p.170) the minimum criteria in the standard of facilities and infrastructure are described as minimum provisions regarding types, ratios, dimensions, criteria, procedures, and legality relating to planning, implementation of procurement and maintenance, as well as supervision of educational facilities and infrastructure. needed to support learning. The greater the support for facilities and infrastructure management, it is assumed that the greater the chance for students and lecturers to maximize their teaching and learning interactions in class. In addition, with the support of complete facilities and infrastructure, it will encourage students to increase their learning motivation.

From the results of the validity test of the infrastructure management variables for 50 students of class 2019-2020, it was obtained from 12 statement items that there were five statements that were declared invalid because the $\mathrm{r}$ count was smaller than the r-table. Thus the five statements are deleted or not included.

After the X1 (infrastructure management) correlation test to $\mathrm{Y}$ (Graduate Quality) at Ma'had Aly Miftahul Huda was tested, a statistical test was carried out using the Statistical Package for Social Sciences (SPSS) and reliability test. For the reliability test in this study, it was carried out by means of one shot (measurement once) and then the results were compared by measuring the correlation between the answers to the statements. Then the results are obtained as in the following table:

Table 2. Reliability Test Results

\begin{tabular}{llll}
\hline Variabel & $\begin{array}{l}\text { Cronbach's } \\
\text { Alpha }\end{array}$ & Standart & Information \\
\hline $\begin{array}{l}\text { Management of facilities } \\
\text { and infrastructure }\end{array}$ & 0,679 & 0,60 & Reliabel \\
\hline
\end{tabular}

Based on the table of reliability test results, it can be seen that the Cronbach's Alpha value for the Infrastructure Management research variable (X1) is above the standard value of 0.60 so it can be said that the research variable has met the reliability test. 
Table 3. Normality Test of Infrastructure Management Variables

\begin{tabular}{|c|c|c|}
\hline \multicolumn{3}{|c|}{ One-Sample Kolmogorov-Smirnov Test } \\
\hline & & $\begin{array}{l}\text { Unstandardiz } \\
\text { ed Residual }\end{array}$ \\
\hline$N$ & & 50 \\
\hline \multirow[t]{2}{*}{ Normal Parameters ${ }^{a \cdot b}$} & Mean & .0000000 \\
\hline & Std. Deviation & 2,05069393 \\
\hline \multirow[t]{3}{*}{ Most Extreme Differences } & Absolute & .087 \\
\hline & Positive & .087 \\
\hline & Negative &,- 066 \\
\hline \multicolumn{2}{|l|}{ Test Statistic } & .087 \\
\hline \multicolumn{2}{|l|}{ Asymp. Sig. (2-tailed) } & $.200^{\mathrm{c} \cdot \mathrm{d}}$ \\
\hline $\begin{array}{l}\text { a. Test distribution is } N \\
\text { b. Calculated from data } \\
\text { c. Lilliefors Significance } \\
\text { d. This is a lower bound }\end{array}$ & $\begin{array}{l}\text { mal. } \\
\text { orrection. } \\
\text { f the true signif }\end{array}$ & nce. \\
\hline
\end{tabular}

Based on the normality test, it can be seen that the KS probability value is 0.200 is greater than the significance level used, namely $0.05(0.200>0.05)$ so that it can be said that the first substructure equation fulfills the normality test.

Table 4. ANOVA Linearity Test

\begin{tabular}{|c|c|c|c|c|c|c|}
\hline \multicolumn{7}{|c|}{ ANOVA $^{a}$} \\
\hline Model & & $\begin{array}{l}\text { Sum of } \\
\text { Squares }\end{array}$ & df & Mean Square & $\mathrm{F}$ & Sig. \\
\hline \multirow[t]{3}{*}{1} & Regression & 82,881 & 1 & 82,881 & 18,296 &, $000^{\mathrm{b}}$ \\
\hline & Residual & 217,439 & 48 & 4,530 & & \\
\hline & Total & 300,320 & 49 & & & \\
\hline
\end{tabular}

a. Dependent Variable: MUTU_LULUSAN

b. Predictors: (Constant), SARANA

From the table above shows that the regression model used to predict the level of graduate quality which is influenced by infrastructure management and lecturer competence at Ma'had Aly Miftahul Huda can be used, because the table above shows that $\mathrm{F}_{\text {count }}>\mathrm{F}_{\text {table }}=10.750>3.20$. This means that the multiple linear regression model can be used in predicting the level of graduate quality which is influenced by infrastructure management and lecturer competence. 
Table 5. Descriptive Analysis Test Results

\begin{tabular}{|c|c|c|c|c|c|}
\hline \multicolumn{6}{|c|}{ Descriptive Statistics } \\
\hline & N & Minimum & Maximum & Mean & Std. Deviation \\
\hline SARANA & 50 & 26 & 35 & 30,22 & 2,179 \\
\hline MUTU_LULUSAN & 50 & 36 & 47 & 41,56 & 2,476 \\
\hline Valid N (listwise) & 50 & & & & \\
\hline
\end{tabular}

The descriptive statistical table above shows that the mean management of infrastructure facilities is 30.22 with a standard deviation of 2.179 with a total of 50 respondents. With a standard deviation of 2.179 , it means that if it is connected with the mean of infrastructure management of 30.22 , then the management of the facilities will be in the range of $30.22 \pm 2.179$ units.

Furthermore, for the average value for the variable quality of graduates of 41.56 with a standard deviation of 2.476 from the number of respondents 50 .With a standard deviation of 2.476 , meaning that if it is related to the average quality of graduates of 41.56 , the quality of graduates will range from $41,56 \pm$ 2.476

Table 6. Multiple Correlation Test Results

\begin{tabular}{l|l|l|l}
\cline { 3 - 4 } \multicolumn{2}{c|}{} & $\begin{array}{l}\text { Management of } \\
\text { facilities and } \\
\text { infrastructure }\end{array}$ & $\begin{array}{l}\text { Quality of } \\
\text { Graduates }\end{array}$ \\
\hline $\begin{array}{l}\text { Management } \begin{array}{l}\text { lacilities } \\
\text { infrastructure }\end{array} \\
\text { and }\end{array}$ & Pearson Corelation & 1 &, $525^{* *}$ \\
\cline { 3 - 4 } & Sig. (2-tailed) & &, 000 \\
\cline { 2 - 4 } $\begin{array}{l}\text { Quality } \\
\text { Graduates }\end{array}$ & $\mathrm{N}$ & 50 & 50 \\
\cline { 2 - 4 } & Pearson Corelation &, $525^{* *}$ & 1 \\
\cline { 2 - 4 } & Sig. (2-tailed) &, 000 & 50 \\
\cline { 2 - 4 } & $\mathrm{N}$ & 50 & \\
\hline
\end{tabular}

Based on the results of data analysis using SPSS, it shows the relationship between infrastructure management (X1) and quality of graduates (Y) with a correlation value of 0.525 with a sample size of 50 and a significance value of $0.000<0.050$, it means that the variable $\mathrm{X} 1$ and the variable $\mathrm{Y}$ have a positive or significant relationship. 
Table 7. Multiple Linear Analysis Test Results

\begin{tabular}{|c|c|c|c|c|c|c|c|c|c|c|c|}
\hline \multicolumn{12}{|c|}{ Coefficients $^{a}$} \\
\hline \multirow[b]{2}{*}{ Model } & & \multicolumn{2}{|c|}{ Unstandardized Coefficients } & \multirow{2}{*}{$\begin{array}{l}\text { Standardized } \\
\text { Coefficients } \\
\text { Beta }\end{array}$} & \multirow[b]{2}{*}{$t$} & \multirow[b]{2}{*}{ Sig. } & \multicolumn{3}{|c|}{ Correlations } & \multicolumn{2}{|c|}{ Collinearity Statistics } \\
\hline & & B & Std. Error & & & & Zero-order & Partial & Part & Tolerance & VIF \\
\hline 1 & (Constant) & 19,318 & 4,910 & & 3,934 &, 000 & & & & & \\
\hline & Sarana & .507 & .148 &, 446 & 3,423 & , 001 & .525 & .447 & .414 & .858 & 1,165 \\
\hline
\end{tabular}

Based on the results of data processing using SPSS, it shows that the coefficients table shows that the multiple linear regression equation model to estimate the quality of graduates is influenced by infrastructure management and lecturer competence:

$$
\begin{aligned}
& Y=a ́ b 1 X 1+b 2 X 2 \\
& Y=19,318+0,507 X 1+0,243 X 2
\end{aligned}
$$

\begin{tabular}{|c|c|c|c|c|c|c|c|c|c|}
\hline \multicolumn{10}{|c|}{ Model Summary } \\
\hline \multirow[b]{2}{*}{ Model } & \multirow[b]{2}{*}{$\mathrm{R}$} & \multirow[b]{2}{*}{ R Square } & \multirow[b]{2}{*}{$\begin{array}{l}\text { Adjusted } R \\
\text { Square }\end{array}$} & \multirow[b]{2}{*}{$\begin{array}{l}\text { Std. Error of } \\
\text { the Estimate }\end{array}$} & \multicolumn{5}{|c|}{ Change Statistics } \\
\hline & & & & & $\begin{array}{l}\text { R Square } \\
\text { Change }\end{array}$ & $\mathrm{F}$ Change & df1 & df 2 & $\begin{array}{l}\text { Sig. F } \\
\text { Change }\end{array}$ \\
\hline 1 & $560^{\mathrm{a}}$ & .314 & .285 & 2,094 & .314 & 10,750 & 2 & 47 & .000 \\
\hline \multicolumn{10}{|c|}{ a. Predictors: (Constant), Kompetensi, Sarana } \\
\hline \multicolumn{10}{|c|}{ b. Dependent Variable: Mutu Lulusan } \\
\hline
\end{tabular}

Table 8. Determination Coefficient Test Results

$$
\mathrm{Kd}=\mathrm{R} 2 \times 100 \%
$$

Where:

$\mathrm{Kd}=(0,560)^{2} \times 100 \%$

$\mathrm{Kd}=0,314 \times 100 \%$

$\mathrm{Kd}=31,4 \%$

The results of data processing show that the $\mathrm{R} 2$ value is 0.560 or $31 \%$, this illustrates that the contribution of infrastructure management and lecturer competence to the increase or decrease in the quality of graduates at Ma'had Aly Miftahul Huda Tasikmalaya is $31 \%$ and the remaining $69 \%$ is a contribution of variables others who were not included in the model proposed in the study.

The results of the significance test for infrastructure management 0.000 $<0.050$ or the results of the $t$ test with $t_{\text {count }} 3.423>t_{\text {table }} 1.2$, then $\mathbf{H}_{\mathrm{o}}$ is rejected and $\mathbf{H}_{\mathbf{a}}$ is accepted. This means that there is a partially significant relationship 
between infrastructure management and the quality of graduates. The magnitude of the influence of infrastructure management on the quality of graduates by $23.4 \%$ is the result of multiplying the Beta and Zero-order values in table 4.17, namely 0.446 X $0.525=0.23415(23.4 \%)$.

Many factors affect the quality of graduates, but infrastructure management has an important role in the implementation of the Tri Dharma of Higher Education. Student motivation to learn is supported by the completeness of infrastructure which ultimately creates enthusiasm in students. Management of higher education facilities is one of the driving forces for a student to carry out learning activities (Silaban, 2016). The management of higher education facilities is carried out through careful planning, good implementation, supervision and proper evaluation.

The completeness of learning infrastructure facilitates learning activities so that the goals will be achieved effectively. The seriousness of students in learning is supported by the completeness of adequate infrastructure, because the quality of learning is influenced by external stimuli in participating in learning (Silaban, 2016). The seriousness of learning arises because of stimulation, both from within and from outside the student who can encourage learning behavior. This is also supported by Munjamil's statement (Munjamil, 2018) which states that the state of the physical facilities where the learning takes place greatly affects the efficiency of learning outcomes.

Limited facilities and infrastructure become an obstacle for students in utilizing learning facilities. This makes students less understanding in receiving some material taught by lecturers and students do not feel at home on campus for too long so that student academic activities are disrupted and not smooth. The negative impact due to inadequate campus facilities on students also greatly affects student learning achievement.

\section{The Effect of Lecturer Competence on the Quality of Ma'had Aly Graduates}

Among the benchmarks for lecturer competence is how far they have mastered the material and applied the right learning model for the material being taught. Lecturers not mastering learning materials have an impact on the quality of students. Law No. 14 of 2005 article 69 classifies lecturer competences into 4 competencies; namely 1) pedagogical competence, namely the ability to process the development of courses in the curriculum, the development of teaching materials, and the design of learning strategies, 2) personality competence, namely personal abilities that reflect a stable, stable, mature, wise, and authoritative personality, become role models for students, and have noble character, 3) social competence, namely the ability to make social relations with 
students, colleagues, employees and the community to support education, and 4) professional competence, namely the ability to master materials in any field of study with various other scientific substances.

Lecturers not only educate students in the classroom, but also outside the classroom. According to Kadir (2018, p. 4). students have a high curiosity and always try new things. The task of the lecturer is to foster this curiosity and make them more curious. A lecturer has a difficult task to produce graduates who are critical, intelligent, open, productive and have noble character as mandated by various demands of stakeholders.

For this reason, competence is an indispensable necessity if you want to improve the quality of learning which is marked by an increase in learning outcomes achieved by students, Hamalik (2002, p.36) argues that the learning process and student learning outcomes are not the time to be determined by the institution, the pattern The structure and content of the curriculum, however, are largely determined by the competence of educators. Competent lecturers are able to create a learning environment that is effective, fun, and able to manage their class, so that student learning is at an optimal level.

The results of the validity test of the lecturer competency variables for 50 students of class 2019-2020. There are 12 statements but there are five statements that are invalid because $r$-count is smaller than $r$-table. Thus, the five statements were deleted or not included.

After the X1 (lecturer competence) correlation test against Y (Graduate Quality) at Ma'had Aly Miftahul Huda was carried out, statistical tests were carried out using the Statistical Package for Social Sciences (SPSS) and reliability tests. For the reliability test in this study, it was carried out by means of one shot (measurement once) and then the results were compared by measuring the correlation between the answers to the statements. Then the results are obtained as in the following table:

Table 9. Reliability Test Results

\begin{tabular}{l|l|l|l}
\hline Variabel & $\begin{array}{l}\text { Cronbach's } \\
\text { Alpha }\end{array}$ & Standart & Information \\
\hline Lecturer Competence & 0,617 & 0,60 & Reliabel \\
\hline Graduate Quality & 0,623 & 0,60 & Reliabel \\
\hline
\end{tabular}

Based on the results of the reliability test, it can be seen that the Cronbach's Alpha value for the Lecturer Competence (X2) variable is above the standard value, namely 0.60 , so it can be said that the research variable has met the reliability test. 
Table 10. Normality Test Results

\begin{tabular}{|c|c|c|}
\hline \multicolumn{3}{|c|}{ One-Sample Kolmogorov-Smirnov Test } \\
\hline & & $\begin{array}{l}\text { Unstandardiz } \\
\text { ed Residual }\end{array}$ \\
\hline$N$ & & 50 \\
\hline \multirow[t]{2}{*}{ Normal Parameters $a, b$} & Mean & .0000000 \\
\hline & Std. Deviation & 2,05069393 \\
\hline \multirow[t]{3}{*}{ Most Extreme Differences } & Absolute & .087 \\
\hline & Positive & .087 \\
\hline & Negative & -.066 \\
\hline Test Statistic & &, 087 \\
\hline Asymp. Sig. (2-tailed) & & $.200^{\mathrm{c} . \mathrm{d}}$ \\
\hline \multicolumn{3}{|c|}{ a. Test distribution is Normal. } \\
\hline \multicolumn{3}{|l|}{ b. Calculated from data. } \\
\hline \multicolumn{3}{|c|}{ c. Lilliefors Significance Correction. } \\
\hline \multicolumn{3}{|c|}{ d. This is a lower bound of the true significance. } \\
\hline
\end{tabular}

Based on the normality table, it can be seen that the KS probability value is 0.200 is greater than the significance level used, namely $0.05(0.200>0.05)$, so it can be said that the first substructure equation fulfills the normality test.

Table 11. ANOVA Linearity Test Results

\begin{tabular}{|c|c|c|c|c|c|c|}
\hline \multicolumn{7}{|c|}{ ANOVA $^{a}$} \\
\hline Model & & $\begin{array}{l}\text { Sum of } \\
\text { Squares }\end{array}$ & df & Mean Square & $\mathrm{F}$ & Sig. \\
\hline \multirow[t]{3}{*}{1} & Regression & 6,075 & 1 & 6,075 & 991 & $324^{b}$ \\
\hline & Residual & 294,245 & 48 & 6,130 & & \\
\hline & Total & 300,320 & 49 & & & \\
\hline
\end{tabular}

From the table above shows that the regression model used to predict the level of graduate quality which is influenced by infrastructure management and lecturer competence at Ma'had Aly Miftahul Huda can be used, because the table above shows that $\mathrm{F}_{\text {count }}>\mathrm{F}_{\text {table }}=10.750>3.20$. This means that the multiple linear regression model can be used in predicting the level of graduate quality which is influenced by infrastructure management and lecturer competence. 
Table 12. Descriptive Analysis Test Results

\begin{tabular}{|l|r|r|r|r|r|}
\hline \multicolumn{7}{|c|}{ Descriptive Statistics } \\
& N & Minimum & Maximum & Mean & Std. Deviation \\
\hline KOMPETENSI & 74 & 24 & 35 & 29,03 & 2,281 \\
\hline MUTU_LULUSAN & 50 & 36 & 47 & 41,56 & 2,476 \\
\hline Valid N (listwise) & 50 & & & & \\
\hline
\end{tabular}

The average value for the lecturer competence variable is 28.46 with a standard deviation of 2.140 from the number of respondents 50 people. With a standard deviation of 2,140, meaning that if it is related to the average competency of the lecturers of 28.46, the lecturers' performance will range between $28.46 \pm 2.140$.

Furthermore, for the average value for the variable quality of graduates of 41.56 with a standard deviation of 2.476 from the number of respondents 50 .With a standard deviation of 2.476 , meaning that if it is related to the average quality of graduates of 41.56 , the quality of graduates will range from 41,56 \pm 2.476

Table 13. Multiple Correlation Test Results

\begin{tabular}{l|l|l|l}
\cline { 3 - 4 } \multicolumn{2}{c|}{} & $\begin{array}{l}\text { Lecturer } \\
\text { Competence }\end{array}$ & $\begin{array}{l}\text { Graduate } \\
\text { Quality }\end{array}$ \\
\hline \multirow{2}{*}{$\begin{array}{l}\text { Lecturer } \\
\text { Competence }\end{array}$} & $\begin{array}{l}\text { Pearson } \\
\text { Corelation }\end{array}$ & 1 &, $378^{* *}$ \\
\cline { 2 - 4 } & Sig. (2-tailed) & &, 007 \\
\cline { 2 - 4 } & N & 50 & 50 \\
\hline Graduate Quality & $\begin{array}{l}\text { Pearson } \\
\text { Corelation }\end{array}$ &, $378^{* *}$ & 1 \\
\cline { 2 - 4 } & Sig. (2-tailed) &, 007 & 50 \\
\cline { 2 - 4 } & N & 50 & \\
\hline
\end{tabular}

Based on the results of data analysis using SPSS, it shows the influence of the variable of lecturer competence (X2) with the variable quality of graduates $(\mathrm{Y})$ having a correlation value of 0.378 with a sample size of 50 and a significance value of $0.000<0.050$, which means that the variable $\mathrm{X} 2$ and Variable $Y$ have a positive relationship or significant. In addition, for the relationship between the infrastructure management variable (X1) and lecturer 
competence (X2) it has a value of 0.376 , which means that there is a positive or significant relationship.

Table 14. Multiple Linear Analysis Test Results

\begin{tabular}{|c|c|c|c|c|c|c|c|c|c|c|c|}
\hline \multicolumn{12}{|c|}{ Coefficients $^{a}$} \\
\hline & & \multicolumn{2}{|c|}{ Unstandardized Coefficients } & \multirow{2}{*}{$\begin{array}{c}\text { Standardized } \\
\text { Coefficients } \\
\text { Beta }\end{array}$} & \multirow[b]{2}{*}{$t$} & \multirow[b]{2}{*}{ Sig. } & \multicolumn{3}{|c|}{ Correlations } & \multicolumn{2}{|c|}{ Collinearity Statistics } \\
\hline Model & & B & Std. Error & & & & Zero-order & Partial & Patt & Tolerance & VIF \\
\hline \multirow[t]{3}{*}{1} & (Constant) & 19,318 & 4,910 & & 3,934 &, 000 & & & & & \\
\hline & Sarana &, 507 & , 148 & . 446 & 3,423 & , 001 & .525 & , 447 & . 414 & 858 & 1,165 \\
\hline & Kompetensi &, 243 & 151 & .210 & 1,611 & 1114 &, 378 & 229 & 195 & 858 & 1,165 \\
\hline
\end{tabular}

Based on the results of data processing using SPSS, it shows that the coefficients table shows that the multiple linear regression equation model to estimate the quality of graduates is influenced by infrastructure management and lecturer competence:

$\mathrm{Y}=\mathrm{a}+\mathrm{b} 1 \mathrm{X} 1+\mathrm{b} 2 \mathrm{X} 2$

$\mathrm{Y}=19,318+0,507 \mathrm{X} 1+0,243 \mathrm{X} 2$

From the above equation, several things can be analyzed, including:

1. Quality of graduates, if without infrastructure management and lecturer competence $(\mathrm{X} 1$ and $\mathrm{X} 2=0)$, then the quality of graduates is only 19,318= 19 units. Meanwhile, if each respondent answers or is increased, it is estimated that the level of graduate quality will increase.

2. The multiple regression coefficients of 0.507 and 0.243 indicate that the magnitude of the increase in the quality level of the graduates for each increase in respondents' answers for the variables of infrastructure management and lecturer competence.

3. The formula above shows that the magnitude of the quality of graduates if it is not influenced by infrastructure management and lecturer competence is 19.318 units. This formula also shows that if infrastructure management and lecturer competence are raised by one point, it will increase the quality of graduates by $51 \%(0.507)$ in infrastructure management and $25 \%(0.243)$ in lecturer competence.

4. The multiple regression equation $\mathrm{Y}=19.318+0.507 \mathrm{X} 1+0.243 \mathrm{X} 2$ which is used as the basis for estimating the quality level of graduates which is influenced by infrastructure management and lecturer competence, will be 
tested valid or not by using the F test hypothesis (simultaneously) and the $t$ test (partially) in hypothesis testing.

Table 15. Determination Coefficient Test Results

\begin{tabular}{|c|c|c|c|c|c|c|c|c|c|}
\hline \multicolumn{10}{|c|}{ Model Summary } \\
\hline \multirow[b]{2}{*}{ Model } & \multirow[b]{2}{*}{$\mathrm{R}$} & \multirow[b]{2}{*}{ R Square } & \multirow[b]{2}{*}{$\begin{array}{c}\text { Adjusted R } \\
\text { Square }\end{array}$} & \multirow[b]{2}{*}{$\begin{array}{l}\text { Std. Error of } \\
\text { the Estimate }\end{array}$} & \multicolumn{5}{|c|}{ Change Statistics } \\
\hline & & & & & $\begin{array}{c}\text { R Square } \\
\text { Change }\end{array}$ & F Change & df1 & df2 & $\begin{array}{l}\text { Sig. F } \\
\text { Change }\end{array}$ \\
\hline 1 & $560^{\mathrm{a}}$ &, 314 &, 285 & 2,094 & 314 & 10,750 & 2 & 47 &, 000 \\
\hline
\end{tabular}

$\mathrm{Kd}=\mathrm{R} 2 \times 100 \%$

Where:

$\mathrm{Kd}=(0,560)^{2} \times 100 \%$

$\mathrm{Kd}=0,314 \times 100 \%$

$\mathrm{Kd}=31,4 \%$

The results of data processing show that the R2 value is 0.560 or $31 \%$, this illustrates that the contribution of infrastructure management and lecturer competence to the increase or decrease in the quality of graduates at Ma'had Aly Miftahul Huda Tasikmalaya is $31 \%$ and the remaining $69 \%$ is a contribution of variables. others who were not included in the model proposed in the study.

The results of the significance test for the competence of lecturers for graduates quality are $0.000<0.050$ and the results of the $t$ test show that $t_{\text {count }}$ $1.611>$ from $t_{\text {table }} 1.2$, so $\mathbf{H o}$ is rejected and $\mathbf{H a}$ is accepted. This means that there is a partially significant relationship between the competence of lecturers and the quality of graduates. The magnitude of the relationship between lecturer competence and graduate quality is $7.94 \%$ which is the result of multiplying the Beta and Zero-order values in table 4.17 above, namely $0.210 \times 0.378=0.07938$ $(7.94 \%)$.

Lecturers who master the lecture material being taught improve student academic achievement because the lecture material presented can be mastered by students completely. This is a problem that is quite difficult for lecturers to feel. The difficulty is because students are not only individuals with all their uniqueness, but they are also social beings with different backgrounds. These results are supported by the theory stated by Isa (Isa Setya Ningrum, 2014) competent lecturers are lecturers who have the ability to plan teaching and learning programs, implement or manage the teaching and learning process, assess the progress of the teaching and learning process, and master the learning 
materials. Lecturers as managers of the learning process are required to have complete preparation.

In learning activities, a lecturer must master his duties which include the task of educating, teaching and training. Educating means continuing and developing life values, teaching means continuing and developing science and technology, while training means developing skills in students (Alam, 2018). Effective teaching and learning conditions must be created because sometimes there is a tendency for lecturers in the teaching and learning process (TLP) to only transfer knowledge without providing direction and guidance to students. In its implementation, a person's learning success is influenced by many factors, in broad terms it can be divided into two types, namely internal factors and external factors.

Lecturer competencies include the ability to plan and prepare for teaching, the ability to master subject matter, the ability to collect and use learning outcomes, the ability to make interpersonal relationships and the ability to take professional responsibility (Alam, 2018). All of these are owned as provisions for carrying out the teaching and learning process. The competence of lecturers in giving lectures to students consists of various attributes including mastery of material, delivery of material, discipline, assessment and creativity. The attributes possessed by the lecturer are used to improve student achievement.

To see the competence of lecturers, it can be obtained by providing an assessment by students of the attributes possessed by the lecturer (Mochamad Hatip, Khoiriyah, Abadi Sanosra, 2018). This attribute will be assessed by students during lectures whether they are satisfied or not. Student satisfaction will be seen by comparing the value of student expectations against the lecturer before lecturing with the perceived value after attending lectures. The results of these student assessments can be used as evaluation material for lecturers to improve the lack of assessment attributes and maintain good assessment attributes. The duties and responsibilities of lecturers are closely related to the competencies required to take up the teaching profession. These competencies are a set of knowledge, skills, and behaviors that must be possessed, internalized and mastered by lecturers in carrying out their professional duties.

These results also support the theory stated by Abdul Kadir (Kadir, 2018) that learning outcomes achieved by a person are the result of the interaction of various factors that influence them both from within (internal factors) and from outside (external factors) of the individual. The success of a student in lecturing activities cannot be separated from the factors above, 
namely the skills of the lecturer in providing variations in teaching can be a means of generating student learning outcomes.

\section{The Influence of Infrastructure Management and Lecturer Competence on the Quality of Graduates}

The ability and skills of a university graduate will be seen from the quality of the university graduates themselves. The issue of the quality of graduates is not something that is instantaneous, easy to achieve and can happen just like that, but it is a complex process and requires deep thought from all competent parties. Therefore, the quality of education graduates is closely related to the learning implementation process which is influenced by many factors, including the curriculum, teaching staff, the learning process, facilities and infrastructure, tools and materials, management, environment and student work training fields.

The management of facilities and infrastructure and the competence of lecturers adjusts to the dynamic development of education. In order for the optimal quality of graduates, it is necessary to support the management of facilities and infrastructure and competence of lecturers. Improving the quality of graduates is inseparable from improving the quality of educational infrastructure and lecturer competence. The quality of graduates must be formulated so that there are clear targets to be achieved for each year or other period. Various inputs and processes must always refer to the quality-results (output) to be achieved.

To test the relationship between these three variables, the researcher used the simultaneous hypothesis test (F test). the result of this simultaneous hypothesis test is to compare the f-count with the f-table. By using the Statistical Package for Social Sciences (SPSS) as follows:

Table 16. Simultaneous Hypothesis Test Results (Test F)

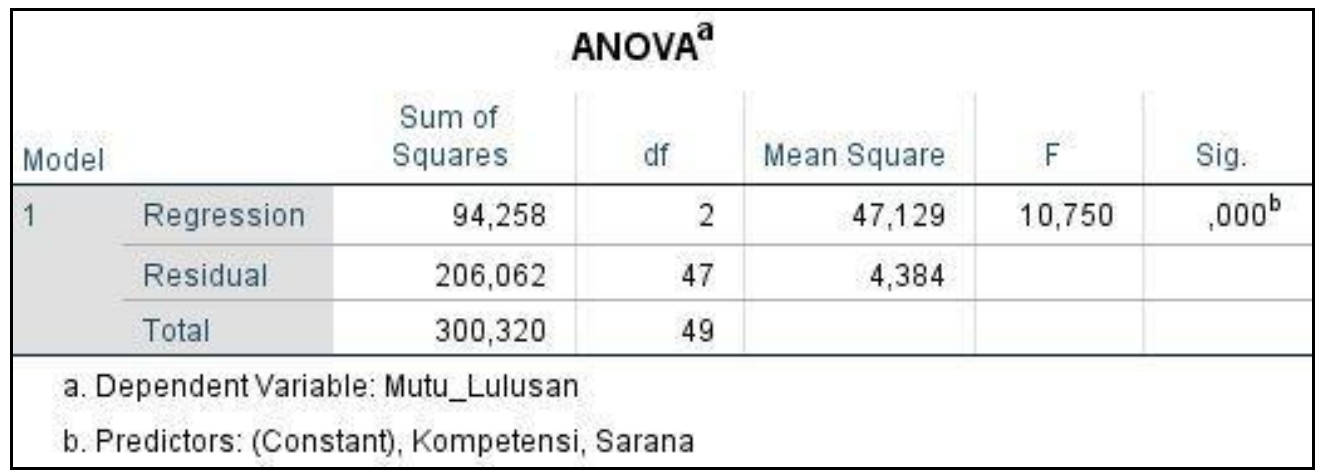


Based on the ANOVA table above, it shows that $\mathrm{F}_{\text {count }}$ is 10.750 with a significant level of 0.000 , while $\mathrm{F}_{\text {table }}$ is at the confidence level of $95 \%(0.05)$ or a significant level of $5 \%$ and degrees of freedom (df) with $\mathrm{dk}$ as 2 and $\mathrm{dk}$ denominator 49 is 3,19 . In both calculations $\mathrm{F}_{\text {count }}=10.750>\mathrm{F}_{\text {table }}=3.19$ and the significance is $0.000<0.05$.

From the results of this hypothesis testing, the decision to take is to reject $\mathrm{HO}$ and accept $\mathrm{Ha}$ (research hypothesis), meaning that jointly or simultaneously, infrastructure management and lecturer competence as a whole have a significant effect on the variable quality of graduates. The magnitude of the relationship between infrastructure management and lecturer competence on the quality of graduates is $45.7 \%$, which is the result of the division of the regression score with the total regression and residual division, namely: 94.258 / $206.062=0.457 \times 100 \%=45.7 \%$.

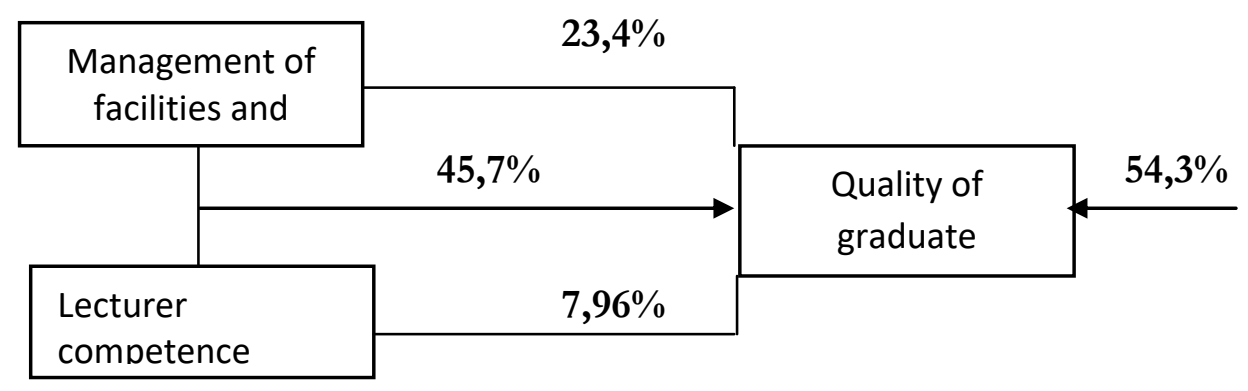

Figure 1. The magnitude of the relationship

Quality in the context of educational outcomes refers to the achievements achieved by educational institutions at any given time). Achieved or educational outcomes (student achievement) can be in the form of a test result of academic ability. It can also be achievements in other fields such as achievements in a particular sport, arts or additional skills. Even the achievements of educational institutions can be in the form of intangible conditions such as an atmosphere of discipline, intimacy, mutual respect, cleanliness, and so on.

\section{CONCLUSION}

Based on the results of hypothesis testing by partial and simultaneous testing, it can be concluded that the management of infrastructure and lecturer competence has a significant effect on the quality of graduates. Simultaneously or collectively, the management of facilities and infrastructure and the competence of lecturers had a significant contribution to the quality of graduates by $45.7 \%$. While the remaining $54.3 \%$ is influenced by other variables not included in this study. Ma'had Aly is an Islamic university which is said to be 
new in the world of education which is held in the pesantren environment so that it needs to be developed more optimally. For future researchers, they should sharpen their abilities in carrying out research. Researchers are expected to be better able to plan research, compile instruments, manage data and analyze data properly so that complete and in-depth research results are obtained and produce research findings that are useful for advances in science and technology.

\section{ACKNOWLEDGMENTS}

Thanks to Mudir Ma'had Aly Miftahul Huda Tasikmalaya for allowing researchers to research in the midst of the current Covid-19 pandemic. Thank you to the student affairs department and all those who helped with this research. Thank you also to the Postgraduate Director of UIN Sunan Gunung Djati Bandung who has facilitated the research.

\section{REFERENCE}

Alam, Y. (2018). Kompetensi Dosen, Motivasi Belajar Mahasiswa dan Dampaknya terhadap Prestasi Mahasiswa dalam Pembelajaran Pengantar Ekonomi ( studi pada mahasiswa program studi Manajemen Informatika AMIK Bina Sriwijaya Palembang ). Manajemen Dan Bisnis Srivijaya, 16(1), 23-30.

Ambarita, I. (2016). Pengaruh Kompetensi Mengajar Dosen Dan Fasilitas Belajar Terhadap Prestasi Akademik. Mahasiswa Melalui Motivasi Belajar Mahasiswa Di STMIK Kaputama Kota Binjai.

Arafah, K. (2019). Pengaruh Sarana Prasarana Akademik, Kualitas Mengajar Dosen, Atmosfer Akademik, dan Motivasi Belajar terhadap Prestasi Belajar Mahasiswa. Parameter, 29(2), 167-184.

Asmawi, M.R. (2005).Strategi Meningkatkan Lulusan Bermutu di Perguruan Tinggi. Makara, Sosial Humaniora, 9 (2), 66-71.

Cahya Edi Setyawan. (2017). Menggagas Model Perguruan Tinggi Agama Islam Berbasis Pesantren. Komunikasi Dan Pendidikan Islam, 6(1), 99-125.

Imam Tobroni, S. R., Pelana, R., Sianipar, G., Guefara, R. L., \& Fathurrochman, I. (2020). Covid 19: Political Cooperation and Ritual Modification of Religious Worship Through Large-Scale Social Restrictions. Systematic Reviews in Pharmacy, 11(12), 644-648.

Indiyati, D., Ghina, A., \& Romadhona, A. F. (2021). Human Resource Competencies, Organizational Culture, and Employee Performance, International Journal of sience and Society (IJSOC). Volume 3 No 1 Tahun 2021.http://ijsoc.goacademica.com/index.php/ijsoc/article/view/251. https://doi.org/10.200609/ijsoc.v2i4.251

Isa Setya Ningrum, S. (2014). Strategi Meningkatkan Kompetensi Dosen 
Universitas Pahttps://doi.org/10.200609/ijsoc.v2i4.251sir Pengaraian Melalui Pendidikan dan Pelatihan. Imiah Cano Ekonomi, 3(2), 117-138.

Kadir, A. (2018). Pengaruh Kompetensi Dosen Dan Motivasi Belajar Terhadap Kemampuan Analisis Statistika Mahasiswa Ftik IAIN Kendari. Al Iz:ah, 13(1), 1-15.

KEMENAG. (n.d.). Statistik Data Pondok Pesantren. Retrieved Oktober 2020, from Pangkalan Data Pondok Pesantren: https:// ditpdpontren.kemenag.go.id

Kholik, A. (2016). Pengaruh Kompetensi Dosen dan Kepuasan Kerja Dosen Terhadap Kinerja Dosen di Universitas Djuanda Bogor.

Mochamad Hatip, Khoiriyah, Abadi Sanosra, dan N. Q. (2018). Kompetensi Dosen, Profesional Dosen, dan Kecerdasan Spiritual dampaknya terhadap Motivasi Belajar Mahasiswa. Jurnal Sains Manajemen Dan Bisnis Indonesia, 8(1), 112-130.

Munjamil, A. (2018). Manajemen Sarana Prasarana dalam Meningkatkan Mutu Pembelajaran di MAN Karanganom Klaten Tabun Pelajaran 2016/2017.

Nadiya, A. N. (2020). Pengelolaan Sarana dan Prasarana untuk Pembelajaran yang Efektif. Jurnal UNESA, 50-62.

Oktaviani, F. d. (2019). Manajemen Sarana dan Prasarana Pendidikan dalam Medukung Proses Belajar Siswa di SDN Puter Kembangbahu Lamongan. Reforma, 8(1), 178-187.

Oktiani, I. (2019). Peningkatan Mutu Lulusan di Madrasah Aliyah Mubammadiyah Pekuncen Banyumas. Purwokerto: IAIN Purwokerto.

Permana, F. (2019). Pendidikan Ma'had Aly Sebagai Pendidikan Tinggi Bagi Mahasantri. Al Qodri Jurnal Pendidikan Sosial Dan Keagamaan, 16(21), 116.

Silaban, N. (2016). Pengaruh Pemanfaatan Sarana dan Prasarana Pembelajaran dengan Tingkat Prestasi Mahasiswa di Unihaz. Manajer Pendidikan, 10(4), 362-366.

Sinta, I. M. (2019). Manajemen Sarana dan Prasarana. Jurnal Isema, 4(1), 77-92. https://doi.org/10.15575/isema.v3i2.5645

Siregar, S. (2015). Statitik Parametrik untuk Penelitian Kuantitatif. Jakarta: Bumi Aksara.

Soraya, N. (2018). Analisis Persepsi Mahasiswa terhadap Kompetensi Dosen dalam Mengajar pada Program Studi PAI Fakultas Ilmu Tarbiyah dan Keguruan UIN Raden Fatah Palembang. Tadrib, 4(1), 183-204.

Tien, Y. C. (2015). Manajemen Peningkatan Mutu Lulusan. Manajer Pendidikan, 9(4), 579-587. 